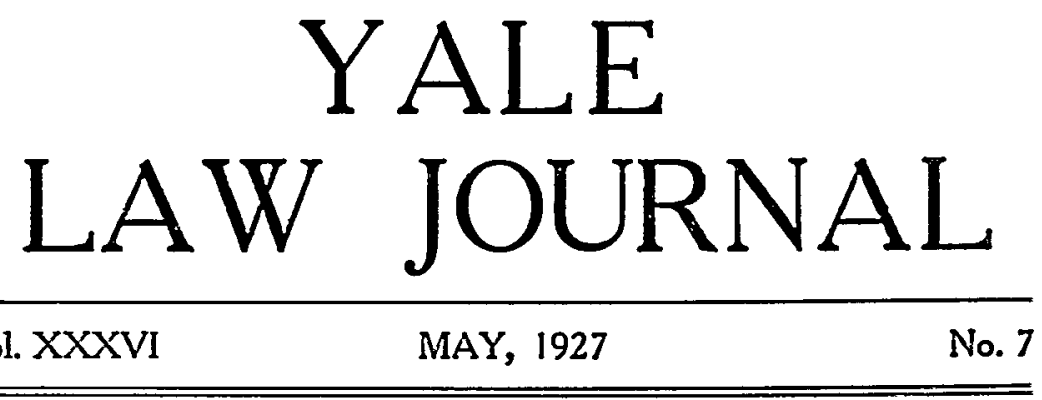

\title{
THE PRESENT STATUS OF THE “LACK OF MUTUALITY" RULE
}

\section{WALTER WHEELER COOK}

The object of any science is to obtain general statements which will accurately describe those aspects of past events which have been noted and also serve as aids in forecasting future events. In the field of the so-called natural sciences, such general statements are called "laws of nature" or "natural laws"the law of gravitation, the law of falling bodies, etc. ${ }^{2}$ As a science develops, it turns out that as a larger and larger number of aspects of natural events are observed or as those previously noted are re-examined with more delicate or more powerful instruments, these general statements, so-called "natural laws," are found to be in need of revision or amendment. At the present time the scientific world, apparently partly because of the invention of better measuring instruments, but also for other reasons, is finding it necessary to revise not merely the statement of particular "laws" but the fundamental concepts in terms of which the "laws" are stated and with which it has worked so successfully for the past three centuries."

\footnotetext{
1 Compare the following passage from Keyscr, Mrathematical PurlosOPHY (1922) 194: "Consider natural science, for example. What is it? For our present purpose, it is sufficiently characterized by its conscious aim, and that aim is discovery of those uniformities in the course of Nature which men of natural science are wont to call natural laws. What, pray, is a natural law? A natural law,-if, strictly spealing, there be such a thing outside the conception thereof, -is fundamentally nothing more nor less than a constant connection among inconstant phenomena: it is, in other words, an invariant relation among variant terms."

See the address on Scientific MIethod and the $L a w$ by the present writer, delivered at the Johns Hopkins University on Commemoration Day, Feb. 22, 1927, printed in (1927) 15 The Jomss Hopkms Aldumi MLiGAZINE, 215.

2 Compare the "epicyclic" condition of astronomical science in the Ptolemaic system, which gave way to the revision of fundamental postulates
} 
The phenomena which furnish the subject matter of legal science consist primarily of the conduct of certain societal agents -judges and similar officials. ${ }^{3}$ The records of the past conduct of these societal agents are found in the law reports. ${ }^{4}$ On the basis of these records and his knowledge of the behavior-patterns of the existing societal agents-members of the present Supreme Court of the United States, of the New York Court of Appeals, etc.-and using a logical technique fundamentally similar to that of other scientists, the student of law endeavors to formulate general statements which will summarize as accurately as possible these past phenomena and also serve as an aid in forecasting future phenomena-i.e., future decisions of whatever group of societal agents he is at the time interested in. ${ }^{\circ}$

introduced by the Copernican hypothesis, with that in modern physical and chemical science in connection with "relativity" and the theory that all atoms are composed of electrons and protons. See WHiteriead, ScinNCE AND THE MODERN WORLD (1925) 184: ". . . the physical doctrine of the atom has got into a state strongly suggestive of the epicycles of astronomy before Copernicus." And at 255: "Science is even more changeablo than theology. No man of science could subscribe without qualification to Galileo's beliefs, or to Newton's beliefs, or to all his own scientific beliefs of ten years ago."

3 Compare the discussion by the present writer in The Logical and Lcgal Bases of the Conflict of Laws (1924) 33 Yale LAw JourNal, 457, 483 et seq.

4 Statutes of course cannot be omitted in a complete enumeration of tho important elements to be considered in forecasting the behavior of the judicial officials. When relevant, they form part of the "situation" which calls forth the behavior of those officials.

${ }^{5}$ In drawing the parallel between other sciences and legal science, tho writer does not mean to suggest that a technique adequate in physics and chemistry will suffice, either in organic sciences such as zoology and botany, or in the so-called social sciences, including legal science. Lawyers aro dealing not merely with organic but with psychological phenomena. Even if one adopts a behavioristic psychology, as the present writer does, ono need not come to the conclusion that what are commonly called mental phenomena can be dealt with adequately in physico-chemical terms. Compare DEWEY, EXPERIENCE AND NATURE (1925) 254: "If we identify, as common speech does, the physical as such with the inanimate we need another word to denote the activity of organisms as such. Psycho-physical is the appropriate term. Thus employed, 'psycho-physical' denotes the conjunctive presence in activity of need-demand-satisfaction, in the sense in which these terms have been defined. In the compound word, the prefix 'psycho' denotes that physical activity has acquired additional properties, those of ability to procure a peculiar kind of interactive support of needs from surrounding media. Psycho-physical does not denote an abrogation of the physico-chemical; nor a peculiar mixture of something physical and something psychical (as a centaur is half man and half-horse); it denotes the possession of certain qualities and efficiencies not displayed by the inanimate." And at 258: "Complex and active animals have, therefore, feelings which vary abundantly in quality, corresponding to distinctive directions and phases-initiating, mediating, fulfilling or frustrating-of activities, bound up in distinctive connections with environmental affairs. They have 
General statements of this kind are called by lawyers "law;" or, more specifically, "rules" and "principles" of the existing law:

As a larger and larger number of phenomena are noted or occur, i.e., as more and more cases are discovered in the reports or are decided by the courts, the lawyer, like the natural scientist, finds it from time to time necessary to reformulate his "rules and principles" to bring them into accord with the totality of his observations. In the course of doing so, it is found that every formulation of a "rule" or "principle" involves the use of terms broader, i.e., capable of a wider range of meaning, than is necessary to include the observed phenomena; and also that these terms gradually shift in meaning with the development of thought upon the subject. The same thing is of course true in the field of any science. "So that now, even when the same assertion is made to-day as was made a thousand, or fifteen hundred years ago, it is made subject to limitations or expansions of meaning, which were not contemplated at the earlier epoch. We are told by logicians that a proposition must be either true or false, and that there is no middle term. But in practice, we may know that a proposition expresses an important truth, but that it is subject to limitations and qualifications which at present remain undiscovered. It is a general feature of our knowledge, that we are insistently aware of important truths; and yet that the only formulations of these truths which we are able to make presuppose a general standpoint of conceptions which may have to be modified. I will give you two illustrations, both from science: Galileo said that the earth moves and that the sun is fixed; the Inquisition said that the earth is fixed and the sun moves; and Newtonian astronomers, adopting

them, but they do not know they have them. Activity is psycho-physical, but not 'mental,' that is, not aware of meanings. As life is a character of events in a peculiar condition of organization, and 'feeling' is a quality of life-form marked by complexly mobile and discriminating responses, so 'mind' is an added property assumed by a feeling creature, when it reaches that organized interaction with other living creatures which is language, communication. Then the qualities of feeling become significant of objective differences in external things and of episodes past and to come. This state of things in which qualitatively different feelings are not just had but are significant of objective differences, is mind. Feelings are no longer just felt. They have and they make sense; record and prophesy." See also Jennings, Diverse Doctrines of Evolution, Their Relation to the Proctice of Science and of Life (1926) 65 SCIENCE, 19.

'It is not always noted that underlying this whole process of "generalization" is an assumption that there are uniformities of conduct on the part of the officials in question which enable us in many cases safely to prophesy. "Stare decisis" means that judges in the Anglo-American legal world have behavior-patterns of a character such that one can as a rule count on their reacting to certain classes of stimuli-"precedents"-in a definite way called "following precedent." Compare Holmes, The Path of the Lave (1897) 10 HARv. L. Rev. 457 et seq. 
an absolute theory of space, said that both the sun and the earth move. But now we say that any one of these three statements is equally true, provided that you have fixed your sense of 'rest' and 'motion' in the way required by the statement adopted. At the date of Galileo's controversy with the Inquisition, Galileo's way of stating the facts was, beyond question, the fruitful procedure for the sake of scientific research. But in itself it was not more true than the formulation of the Inquisition. But at that time the modern concepts of relative motion were in nobody's mind; so that the statements were made in ignorance of the qualifications required for their more perfect truth. Yet this question of the motions of the earth and the sun expresses a real fact in the universe; and all sides had got hold of important truths concerning it. But with the knowledge of those times, the truths appeared to be inconsistent." ?

It is the purpose of the present discussion to examine the process just described at work in a particular field of law, viz., that usually included under the phrase, "Iack of mutuality as a defense to the specific performance of contracts." The task is undertaken in the belief that thereby light will be thrown not only upon the particular subject matter, but also upon the more general problem of the technique of legal reasoning as well.

We begin our discussion with the famous statement of Lord Justice Fry in his work upon Specific Performance, the first edition of which was written in 1848.8 This statement is selected because it has played so large a part in the opinions of courts in America and so much has been written about it by text writers and in the law magazines. The statement is as follows:

"A contract, to be specifically enforced by the court, must be mutual,--that is to say, such that it might, at the time it was entered into, have been enforced by either of the parties against the other of them." 9

Perhaps the most interesting thing about this passage is that, as appears from the pages immediately following it in the first edition of Fry's work, it was on its face a misdescription of the phenomena in question-the past decisions of the courts of equity in England. The result was, as might have been expected, that the author was immediately driven to state a series of "exceptions" to his "rule." A procedure of this kind is scientific only if it is impossible to describe the observed data by some other generalization that will not require exceptions in order to cover

\footnotetext{
7 WHITEHEAD, op. cit. supra note 2 , at 255.

8 FrY, Specific Performance (1st ed. 1848) 133, §286. The passago stands unaltered in the sixth (English) edition, published in 1921, at 210.

9 Nate the similar statement in PoMeroy, EQUITY JURISPRUDENCE (Stud. ed. 1907) \&1405-a statement, however, which was probably not intended by the author to be taken as literally as the courts did. See Pomerox, SPECIFIC PERFormaNCe (2d ed. 1897) § 165.
} 
the data. It happens at least occasionally in other fields of science that such an impossibility does exist for a time in some portion of the field. Thus, by Newton's law of gravitation, irregularities in the motion of the planet Mercury's orbit were inexplicable and had to be treated as an exception. Einstein's law, however, accounts for these. "Curiously enough, there is more than one alternative formula, based on the new theory of multiple space-time systems, having the property of embodying Newton's law, and in addition of explaining the peculiarities of Mercury's motion. The only method of selection between them is to wait for experimental evidence respecting those effects on which the formulae differ:" 10

It is, of course, recognized by all scientists that a general rule which necessitates exceptions should not be adopted if it can be avoided. "The question that naturally forces itself upon the attention of the careful thinker is: How shall we decide between rival hypotheses? There are two principles (which may finally be brought to one, known as the law of parsimony) used to aid in making the choice. These principles are known as that of superposition and that of simplicity. If one of the rival hypotheses accounts for all the facts that the other accounts for and more in addition, that one undoubtedly has the advantage. If hypothesis $a$ accounts for ten facts, and hypothesis $b$ accounts for the same ten and two more, hypothesis $b$ should be chosen. The simpler of two rival hypotheses should also be chosen. Simplicity need not be thought of as 'easy to understand,' but rather as accounting for the facts as they are discovered without the introduction of special hypotheses to account for particular facts as they develop. Such a special hypothesis is called an hypothesis ad hoc, i.e., one to account for this particular casc, a case that does not seem to be accounted for in terms of the general hypothesis already accepted. When we have an hypothesis or theory which should account for all the facts, but which requires constant readjustment, constant 'amendments,' to make it 'work,' we may properly become skeptical as to the genuineness of the hypothesis. Such amending should be a reminder that it might be possible to discover another hypothesis which would not require this. We may call these amendments ad hoc hypotheses-hypotheses to account for special cases that have arisen. Of two hypotheses, the simpler is that which does not so often need to be 'amended,' or added to as special cases arise.

10 WHITEHEAD, op. cit. supra note 2, at 173 . Note that at the present time no single generalization will account for all the observed phenomena connected with light. For some, the wave theory is sufficient; for others, the corpuscular theory. Leiris, The ANatomir of Scresce (1926) 118, ct seq., suggests a theory which he believes will harmonize the two. 
The simpler one accounts for the facts with the smallest number of significant amendments." 11

Before noting attempts to reformulate the "law" upon the subject by various writers, it may be well to recall to mind the well-known statement of the eight exceptions to Fry's rule which the late James Barr Ames believed would be recognized by most Anglo-American courts.

"(1) A bilateral contract between a fiduciary and his principal is often enforced in favor of the principal, although not enforceable against him.

"(2) A similar contract procured by the fraud or misrepresentation of one of the parties may be enforced against him, although not by him.

"(3) In England, one who, after making a voluntary settlement, has entered into a contract to sell the settled property, may be compelled to convey, although he cannot force the buyer to accept a conveyance.

"(4) A vendor, whose inability to make a perfect title debars him from obtaining a decree against the buyer, may in many cases be forced by the buyer to convey with compensation.

"(5) Notwithstanding the opinions of Lord Redesdale and Chancellor Kent to the contrary, a party to a bilateral contract, who has signed a memorandum of it, may be compelled to perform it specifically, although he could not maintain a bill against the other party who had not signed such a memorandum.

"(6) A contract between an infant and an adult may be enforced against the adult after the infant comes of age, although no decree could be made against the plaintiff.

"(7) A plaintiff who has performed his part of the contract, although he could not have been compelled in equity to do so, may enforce specific performance by the defendant.

"(8) One who has contracted to sell land not owned by him, and who, therefore, could not be cast in a decree, may, in many

11 Cunningham, TextвooK of Logic (1924) 255. Compare the following illuminating passage in WHITEHEAD, op. cit. supra note 2, at 261: "It is easy enough to find a theory, logically harmonious and with important applications in the region of fact, provided you are content to disregard half your evidence. Every age produces people with clear logical intellects, and with the most praiseworthy grasp of the importance of some sphere of human experience, who have elaborated, or inherited, a scheme of thought which exactly fits those experiences which claim their interest. Such people are apt resolutely to ignore, or to explain away, all evidence which confuses their scheme with contradictory instances. What they can not fit in is for them nonsense. An unflinching determination to take the whole evidence into account is the only method of preservation against the fluctuating extremes of fashionable opinion. This advice seems so easy, and is in fact so difficult to follow." 
cases, by acquiring title before the time fixed for conveyance, compel the execution of the contract by the buyer." 28

Adopting an obviously sound technique, Ames proceeded to reformulate the "law" as to lack of mutuality, and succeeded in producing a generalization which was both more inclusive and more "simple" (in the sense described in the passage quoted above) than Fry's rule. Ames's formulation was as follows:

"Equity will not compel specific performance by a defendant if, after performance, the common law remedy of damages would be his sole security for the performance of the plaintiff's side of the contract." 13

As the "law" developed, i.e., as new cases were decided by the courts (or the old ones re-examined by students), other writers also attempted to rephrase the rule, so as to make it more comprehensive. The following are interesting and important examples.

"If, after a decree against defendant, there remain to be done, under the contract, acts on plaintiff's part of such a character either that the court cannot frame a decree to enforce them, or that it cannot carry out such decree without unduly taxing the time and attention of the court, specific performance is usually refused. Thus relief is refused where plaintiff's promise is too indefinite to be enforced; where the contract calls for strictly personal services on the part of plaintiff, such as care and support, or business services, as agent, manager, surveyor, partner, attorney, etc.; or where it calls for building or operation of a railroad, other construction work, or other continuous acts." 14

"Equity will not grant the plaintiff specific performance of a bilateral contract if, after the defendant's forced performance, the plaintiff's own obligation will remain unperformed and is of such a nature that, at the time for its fulfillment, equity would, on grounds independent of mutuality, refuse specific performance of it,- the one possible limitation to this rule being that equity might give the plaintiff specific performance if the defendant's assumed common law remedy of damages would be fully adequate." 15

The question now arises: Which, if any of these, gives us a

12 AMIES, LECTURES ON LEGAL HISTORY (1913) 370.

13 AMES, op. cit. supra note 12 , at 371 . Note also the following statement at 376: "It is evident, from a consideration of the eight classes of cases just discussed, that the rule of mutuality, as commonly exprezsed, is inaccurate and misleading. The reciprocity of remedy required is not the right of each party to the contract to maintain a bill for specific performance against the other, but simply the right of one party to refuse to perform, unless performance by the other is given or assured."

I4 John Norton Pomeroy, Jr., in 36 Cyc. 629.

15 Comment in (1917) 27 YaLe LaW JourNax, 261. This phrasing, the present writer knows, was essentially due to W'esley Newcomb Hohfeld, although the comment in question was by one of his students. 
generalization which will include all the phenomena without d'esorting to any hypothesis ad hoc, i.e., exceptions? Here we need to note that we cannot expect that all the decisions of over a half hundred courts of last resort in the Anglo-American legal world will fit any single generalization. If we narrow our question, then, to some one jurisdiction-say to England, or New York, or Kansas, for example, our problem is: Is any one of the formulas given adequate for this particular jurisdiction? ${ }^{10}$

If we look first at the mother country, it seems clear that none of the generalizations will accomplish this purpose. The most conspicuous source of trouble is the famous case of Lumley $v$. Wagner, ${ }^{17}$ in which, it will be recalled, Lord Chancellor St. Leonards enjoined the breach of an express negative promise where, according to settled rules governing the exercise of equitable jurisdiction, he would not and did not specifically enforce either the affirmative promise of the defendant or that of the plaintiff. The long line of cases in this country which has followed that decision shows that in at least a large number of American jurisdictions the same source of difficulty exists.18 Even if we admit, as is pointed out by Ames, that the injunction in this group of cases is made conditional upon the continuing performance by the plaintiff of his affirmative promise, ${ }^{10}$ we surely cannot say "that performance by the plaintiff is given or assured" at the time the decree is entered, if by "assured" we mean a legal guarantee of performance. For example, in such cases as Lumley $v$. Wagner, there is nothing except the prospective loss of profit to prevent the employer from refusing at

${ }^{16}$ It may be pointed out in passing that the physicist and chemist frequently deal only with statistical averages. For example, the "behavior" of a piece of, say, sodium the size of a pea is the average of the behavior of many millions of atoms, and no one knows the chemical behavior of an individual atom or that it is exactly like that of any other atom. Indeed, according to current notions, each atom is a very complex "solar system" of protons and electrons, which puts still more doubt into the matter. Compare Cohen, Mechanism and Casualty in Physics (1918) 15 THE JourNaL of Philosophy, PSychology AND SCIentific Metrod, 365. Note that in thermodynamics the physical scientist admits his inability to do more than deal with millions of molecules in a group; he is utterly unable to deal with the individual molecules. See chapter on "Probability and Entropy" Leifis, THe ANATOMY of SCIENCE (1926) 135-162. The lawyer, however, must predict the conduct of individuals-Judge $\mathrm{X}$, Judge $\mathrm{Y}$, etc. Comparo Cohen, op. cit. supra: "The great difference between physical and social phenomena would thus be due to the fact that in the latter, individual variations obtrude themselves, while in the physical realm the constituent individuals or atoms are for the most part beyond our range of obsorvation."

171 De Gex, M. \& G. 604 (1852).

18 See the cases and notes in 2 CoOK, CASES ON EQUITY (1925) 151 et scq.

19 From this point of view-indeed from any point of view-the decision in Montague v. Flockton, L. R. 16 Eq. 189 (1873) seems indefensible. 
any moment to go on employing the singer or actor. If the refusal should occur, as it might, in the middle of the opera season, the singer's only remedy would be an action at law for damages, in spite of the fact that the singer had not only obeyed the injunction but continued to perform the affirmative part of the bargain by continuing to sing. Of course, the injunction would fall with the breach by the employer: $0^{\circ}$ Similar difficulties arise in connection with cases like Hill v. Croll and Dictrichscn v. Cabburn.21 In such cases if the plaintiff (seller or buyer) chooses to stop supplying or receiving the goods, the defendant is left to sue at law for damages, even though he has obeyed the injunction and performed the affirmative part of his promise to take or supply the goods when tendered. The condition in the injunction merely assures him that he will not have to keep on refraining from dealing elsewhere unless the plaintiff performs; it leaves him after part performance of both the negative and affirmative parts of his promise with no legal assurance whatever that the plaintiff will perform his side of the bargain.?

The difficulty is not obviated if we endeavor to apply the rule as stated by John Norton Pomeroy, Jr, as quoted above. There do, "after a decree against defendant, remain to be done, under the contract, acts on plaintiff's part of such a character either that the court cannot frame a decree to enforce them, or that it cannot carry out such decree without unduly taxing the time and attention of the court." Nor does the rule suggested in the note in the YALE LAW JOURNAL help us out of the difficulty, for after the "compelled performance" of the defendant, [refraining from singing, say, for a week or month] "the plaintiff's own obligatiion will remain unperformed [at least in part] and is of such a nature that, at the time for its fulfillment, equity would, on grounds independent of mutuality, refuse specific performance of it."

Let us now examine another suggested reformulation of the rule as given by Professor Barry Gilbert in the California Law

\footnotetext{
20 Note also that the refusal to go on might be put by the employer on the ground that the singer or actor was not performing in good faith and that if this were set up as the reason for refusing to allow him to continue singing or acting, the court would apparently become involved in deciding the kind of question which it felt itself not fitted to answer, viz., whether the singer or actor was conscientiously carrying out the affirmative.

${ }^{21}$ See Hills v. Croll, 2 Phil. 60 (1845) (in which the injunction was denied. Ames seemed to take the view that it should have been granted. See 1

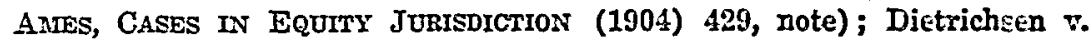
Cabburn, 2 Phil. 52 (1846).

22 Note that if, as seems to have happened in Lumley $v$. Wagner, the defendant performs all of the negative but not the affirmative, he becomes
} 
Review." "Attempting to codify these two cases into the rule, do we not find the result to be something like this: Equity will not compel specific performance by a defendant if after performance the common law remedy of damages would be his sole security for the performance of the plaintiff's side of the contract, excepting in the case of the enforcement of negative covenants in personal service contracts where affirmative performance by the defendant would be continuous, synchronous with, and dependent upon performance by the plaintiff; and in this case equity will enjoin a breach of the negative covenant so long as the plaintiff is not guilty of a breach of his side of the contract. Or this: Equity will not compel specific performance by a defendant if after performance by the defendant it is either certain or probable that the defendant will have to resort to the common law remedy of damages to secure performance of the plaintiff's side of the contract."

Note that the rule, as first stated, frankly contains an exception, i.e., specific performance is admittedly granted in certain cases although the usually required mutuality is lacking. Recognizing this, Professor Gilbert proceeds in the second form of statement, by inserting the words "or probable," to obtain at least the appearance of having a rule uniformly applicable without exceptions. If we examine the "rule" in this form, the question at once arises, what is meant by saying that it "is probable that a defendant will have to resort to the common law remedy of damages to secure performance of the plaintiff's side of the contract?" Presumably factual probability is meant. It requires but slight analysis to discover that our rule now obviously contains what a student of modern mathematical logic would call a "real variable" - a term to which in a new case any meaning the court chooses may be given, depending upon the court's notions as to the desirability or not of granting an injunction in the particular case. ${ }^{24}$ In pointing this out, it is not the intention to

entitled to exactly nothing, for the salary is to be paid for both and not for one. However, in spite of all theoretical objections, the doctrine seoms to be recognized by the profession as practical and satisfactory. At lenst, the writer is informed, in arbitration awards made under the Now York Arbitration Statute the arbitrators assume the doctrine to be sound and so make awards calling for injunctions.

23 (1916). 4 CALIF. L. Rev. 114, 130.

24 KEYSER, op. cit. supra note 1, at 49: "Propositional Function is, perhaps, the weightiest term that has entered the nomenclature of logic. . . in the course of a hundred years. ... [ [It] is any statement containing one or more real variables, where, by a real variable, is meant a name or other symbol whose meaning, or value as we say, is undetermined in the statement but to which we can at will assign in any order we please one or more values, or meanings, now one and now another." 
criticize this as a defect in Professor Gilbert's statement of the rule. If it be assumed that a single general "rule" is to be formulated so that there will be no exceptions to account for particular groups of cases, this is perhaps the best that can be done. It has at least the merit of calling attention to the faes that it is not possible to formulate any rule that will be capable of purely "logical" ${ }^{25}$ application to a really new case. In this respect the statement merely makes somewhat more obvious what in the case of other statements of "rules of law" is more usually discoverable only by a somewhat careful analysis..$^{* 3}$

At this point in our discussion, it may perhaps be instructive to refer briefly to the career of Lord Justice Fry's rule in the courts of New York-a jurisdiction in which it had great influence. The New York history is so thoroughly worked out in Dean (now Mrr. Justice) Harlan F. Stone's well-known article that no attempt will be made even to summarize it here. Since that discussion was written, the whole tendency of the New

It should perhaps be added that "rules" of law, as well as legal "principles," when used in thinking about "new" cases, i.e., cases which are thought of as not covered by any precedent exactly in point, prove to be "propositional functions," and not "propositions" (statements that are "true" or "false") in the sense of modern logic. Compare Kexser, op. cit. supra note 1, at 149. They become "propositions" only after the case has been decided. See infra note 26.

25 "Logical" here is used in its ordinary sense as synonymous with deductively logical.

${ }^{26}$ See supra note 24. Consider, for example, almost any "rule" of lawsay the rule in some states that a father is responsible for the torts of his minor child when he has furnished the child with a "dangerous instrument." "Dangerous instrument" will prove upon examination to be a "real variable," i.e., a term to which a court can, in dealing with a new case, give a meaning which when given will decide the case in the way the particular court may for some other reason desire. The "deduction" which follows is only a way of stating the result; it is not the reason for the decision. Compare MIr. Justice Holmes, The Path of the Law (1897) 10 H.Inv. L. REv. 465, reprinted in Collected Legal Papers, 181: "You can give any conclusion a logical form." In Law in Science-Scicnce in Lave (1899) 12 HaRv. L. REv. 460, reprinted in Collected Legal PAPERS (1921) 299, the same learned writer says: "But I think it most important to remember whenever a doubtful case arises, with certain analogies on one side and other analogies on the other, that what really is before us is a conflict between two social desires, each of which seeks to extend its dominion over the case, and which cannot both have their way. The social question is which desire is stronger at the point of conflict. The judicial one may be narrower, because one or the other desire may have been expressed in previous decisions to such an extent that logic requires us to assume it to preponderate in the one before us. But if that be clearly so, the case is not a doubtful one. Where there is doubt the simple tool of logic does not suffice, and even if it is disguised and unconscious, the judges are called on to exercise the sovereign prerogative of choice."

27 (1916) 16 CoL. L. REv. 443. 
York law has been altered by the case of Epstein v. Gluckin, ${ }^{28}$ in which it was held that the assignee of a vendee is entitled to specific performance against the vendor. In the opinion in that case, written by Judge (now Chief Judge) Cardozo, the "law" as to lack of mutuality is stated as follows: "If there ever was a rule that mutuality of remedy existing, not merely at the time of the decree, but at the time of the formation of the contract, is a condition of equitable relief, it has been so qualified by exceptions that, viewed as a precept of general validity, it has ceased to be a rule to-day. . . . . What equity exacts to-day as a condition of relief is the assurance that the decree, if rendered, will operate without injustice or oppression either to plaintiff or to defendant. . . . Mutuality of remedy is important in so far only as its presence is essential to the attainment of that end. The formula had its origin in an attempt to fit the equitable remedy to the needs of equal justice. We may not suffer it to petrify at the cost of its animating principle." 29

"The assurance that the decree, if rendered, will operate without injustice or oppression either to the plaintiff or the defendant"-when does that exist? Obviously, here is no rule that can be applied to new situations by mere logic; all it can do is to aid one in recalling situations already passed upon in prior decisions and comparing them with the new situation, and so to decide the case without "injustice or oppression." Apparently this is all that any rule can do. ${ }^{30}$

If we consider a little more carefully cases of the type of Dietrichsen v. Cabburn, ${ }^{31}$ we can readily see what has led courts to reach the results they have. In that case it was admitted by demurrer that the defendant had agreed to give the plaintiff as wholesale distributor a larger discount from the retail price of a certain patent medicine than he would give to any other per-

28233 N. Y. 490,135 N. E. 861 (1922), discussed in (1922) 22 CoL. L. REv: 682; (1922) 36 HARV. L. REv. 229; (1923) 32 YALE LAW JOURNAL, 832. The influence of writers in the legal periodicals upon the trend of legal development upon this point in New York clearly appears from the references in the opinion to the discussions by Ames, Stone, etc.

$29233 \mathrm{~N}$. Y. at $493-4,135 \mathrm{~N}$. E. at 862.

30 See the chapter on "The Nature of Principles" Dewey, HuMraN NATURE AND CONDUCT (1922) 238-247. Dewey is discussing moral principles, but what he says applies equally to legal principles and rules as well. Note especially the following passage, at 240-241: ". . . it is clear that all principles are empirical generalizations from the ways in which previous judgments of conduct have practically worked out. When this fact is apparent, these generalizations will be seen to be not fixed rules for deciding doubtful cases, but instrumentalities for their investigation, methods by which the net value of past experience is rendered available for present scruting of new perplexities. Then it will also follow that they are hypotheses to be tested and revised by their further working."

31 Supra note 21. 
son during the period in question. This was done because the plaintiff, as an extensive seller of patent medicines, had unusual facilities for advertising the same. It was also admitted that after the plaintiff had incurred considerable expense in advertising the oil, whereby it had obtained great celebrity and an extensive sale, and although he had in all respects performed the agreement on his part, the defendant had broken the agreement. We are thus confronted with a situation where the plaintiff has already conferred upon the defendant a factual economic benefit of a character such that it leads to the conclusion that there is no "injustice or oppression" in compelling the defendant to observe the negative agreement, even though there is no legal assurance or guarantee that the plaintiff will keep on performing his part of the bargain. In such cases we can perhaps fairly say that the value of the negative has already been paid for:sa The situation obviously would be different if nothing had been done and the bargain remained purely executory.

The breakdown of the attempt to state some simple rule that can be automatically applied appears clearly when we consider cases like Zelleken $v$. Lynch. ${ }^{33}$ In that case the defendant had agreed to execute a lease of the land in controversy for a term of years; the plaintiff had agreed to develop the property for mining purposes in good faith and in a miner-like manner; the plaintiff had gone into immediate possession of the property, had occupied it continuously for a period of more than three years before asking specific performance; had in good faith carried out the terms of the contract, installed machinery, erected improvements, and otherwise developed the property until it had become very valuable, and in so doing had expended the sum of $\$ 30,000$. The defendant had refused to execute the lease; the plaintiff asked specific performance. Lack of mutuality was set up as the defense. It was admitted by the court that a decree ordering the plaintiff to continue the mining operations

32 Note that in Daly v. Smith \& Smith, 88 N. Y. Super. Ct. 15s (1874), there was a special provision in the contract that if the defendant should refuse to fulfill her part and should attempt to perform in any other theatre before the termination of her agreement with the plaintifi, the plaintiff might, by legal process or otherwise, restrain her from so performing, on payment to her during such restraint of a sum equal to onequarter of the salary to be paid to her under the contract in lieu of the said, or any other salary under the agreement during the period covered. To decree specific performance of the negative in a case of this lind is merely to carry out the express agreement of the parties and the defendant of course receives that part of the consideration which, by the agreement, was apportioned to the negative part of the contract.

3380 Kan. 746, 104 Pac. 563, 46 L. R. A. (x. S.) 659 (1909), noted in (1910) 23 HARv. L. REv. 294. Compare St. Joseph Hydraulic Co. v. Globe Tissue-Paper Co., 156 Ind. 665, 59 N. E. 995 (1901) with Fowler Utilities Co. v. Gray, 168 Ind. 1,79 N. E. \$97, 7 L. R. A. (N. s.) 726 (1901). 
for the remainder of the term would not be granted. In spite of this, a decree for specific performance was rendered. The result can be accounted for under Professor Gilbert's rule if we reach the conclusion that it was factually not probable that the plaintiff would abandon the mining operations after the decree was entered. It is obvious that he would not do so unless continued mining would in his judgment be unprofitable. ${ }^{34}$ The result can be described equally well in the terms used by Judge Cardozo in Epstein v. Gluckin. No "injustice or oppression" will result from the decree.

The result in Zelleken $v$. Lynch is obviously a satisfactory one; any other would result in hindering the development of the natural resources of the state. This assumes of course that the development of these resources is something desired by the dominant elements in the community. ${ }^{35}$ The following extract from the enlightened opinion of Judge Burch is instructive:

"Take the facts of this case. The defendant put the plaintiff in possession under the oral agreement. The plaintiff is without fault, and shows three years of faithful and sincere performance. The plaintiff greatly enhanced the value of the property by the expenditure of large sums of money in improvements and in development work, and has placed itself in a position to enjoy the very fruits of the contract which were in the contemplation of the parties when it was made. The parties appear to have been competent, there is nothing to indicate that the contract was not fairly concluded, and it seems to be reasonable and just in all its provisions. There is no way to estimate money damages which would adequately compensate the plaintiff should it be compelled to vacate the premises. If equity has no remedy to prevent the defendant from confiscating to its own use this increment to the value of its land, from compelling the plaintiff to sacrifice its expenditure of time and labor and money, and from cutting off the plaintiff from the just profits of the venture, it is a very anaemic system, and needs to be recruited with a stock of robust, virile principles which will enable it to cope

34 The case does not fall under the exception of Professor Gilbert's first rule, as it grants specific pexformance of an affirmative promise and his exception applies only to specific performance of negative promises.

${ }_{35}$ In his thinking, every judge, like any other human being, either consciously or, perhaps more frequently, unconsciously, necessarily assumes some "end" or "ends" as desirable, and his thinking goes on on this basis. Such assumptions should be thought of as parts of the system of "postulates" which seem to underlie all so-called "proof" in any branch of science. The reference here is not to the deductive "proof" of the mathematician, but to that of the natural scientist. Recently an eminent chemist has asked whether so-called scientific "proof" is anything more than "an attempt to render plausible new statements by correlating them with others that are already accepted." Lewis, op. cit. supra note 10, at 90. And compare the same author's remarks at 71-72 in the same work. 
with fraud. Whatever the situation of the parties may have been at the beginning is of no consequence now. Their affairs have reached a stage where the plaintiff's claims appeal to conscience and are unopposed by any countervailing cauity on the defendant's side. The plaintiff is not within the principle which denies specific performance at his behest when he may, under the law or under the contract, decline to perform on his part the moment the decree is entered. He cannot rightfully refuse to fulfill his agreement. Should a wrongful refusal occur, the defendant would be entitled to redress, and doubtless either the law or equity would provide him a remedy. It may be that some form of injunctive relief to prevent a breach of the contract would be awarded, or it may be that reparation in dameges could be made. But the court has no occasion to anticipate culpable conduct on the plaintiff's part and speculate upon how the defendant might protect himself should he sometime need protection. It may be assumed that the plaintiff will obey the law and lieep its promise. Manifestly it is just and equitable and will thwart a fraud now to decree specific performance in the plaintiff's favor, and manifestly it would be unjust and inequitable and would allow the perpetration of a fraud not to do so. That is sufficient. If scientific or other considerations dcmand a formula goverining the subject, whoever needs can phrase one on that basis." 36

Note once more that the result can be squared only with a vague rule like that formulated by Professor Gilbert, or the equally vague statement of Judge Cardozo. We can say either that it is not in fact probable that the defendant will have to use his common law remedy of damages against a defaulting plaintiff, or that no injustice or oppression will result if we compel the defendant to grant the lease. Note that Judge Burch frankly abandons any attempt to state a rule that will cover the case. Compare his opinion with that of the Michigan court in the well-known case of Rust v. Coniad. ${ }^{37}$ As is well lmown, the decision in the latter case proved so detrimental to the derelopment of the mineral resources of the state that the legislature intervened. ${ }^{38}$

The substance of Lord Justice Fry's alleged rule as to lack of mutuality was made a part of the California Civil Code. As a result, it has helped in leading the courts of that state to deny specific enforcement of negative agreements not to sell elsewhere made by producers of agricultural products who join co-operative marketing associations and agree to market their goods ex-

${ }^{36}$ The italics are the present writer's.

37 47 Mich. 449, 11 N. W. 265, 41 Am. Rep. 720 (1882).

38 Mich. Laws, 1883, Act No. 73; Grummett v. Gingrass, 77 Mieh. 369, 43 N. W. 999 (1889). 
clusively through the association. Assuming, as seems to be the case, that the dominant elements in the community regard such associations as desirable parts of the economic organization it is clear that such agreements ought to be legally binding, but it is also obvious that they cannot be effective unless the association can prevent the members from marketing through other dealers. $^{39}$ Statutes are now being passed in many states to do away with or to forestall the effects of illiberal decisions of this kind. Many of these statutes provide specifically for specific performance or for injunctions. ${ }^{40}$

In closing the discussion, it may be emphasized that there is nothing unique about these experiences with the "lack of mutuality" rule. Every attempt to reduce the law in a given field to a rule which can be applied automatically to really new situations by the processes of deductive logic, is of necessity foredoomed to failure. In the words of Mr. Justice Holmes, "But certainty generally is illusion, and repose is not the destiny of man." 41 All that either so-called "principles" or "rules" can do is to aid us to bring to bear upon new situations the relevant and competing analogies. The rules are generalizations which, so far as they are general, are empty.42 The choice between the competing analogies involves, as the same learned author from whom we have just been quoting says, ". . . a judgment as to the relative worth and importance of competing legislative grounds, often an inarticulate and unconscious judgment, it is true, and yet the very root and nerve of the whole proceeding. You can give any conclusion a logical form. You can always imply a condition in a contract. But why do you imply it? It is because of some belief as to the practice of the community or of a class, or because of some opinion as to policy, or, in short, because of some attitude of yours upon a matter not capable of exact quantitative measurement, and therefore not capable of founding exact logical conclusions. Such matters really are battle grounds where the means do not exist for determinations that shall be good for all time, and where the decision can do no more than

39 Poultry Producers of Southern California, Inc. v. Barlow, 189 Calif. 278, 208 Pac. 93 (1922). The decision also involved the absurd assumption that an agreement by a corporation to market goods is an agreement for "personal services" and cannot be specifically enforced for that reason. This is obviously a reductio ad absurdum of the "personality" theory of the corporation. And see Henderson, Co-operative Marketing Associations (1923) 23 CoL. L. REv. 91, 99, as to the feasibility of specific performance in this group of cases.

40 See Cook, op. cit. supra note 18, at 214, note; Henderson, loc. cit. supra note 39.

41 Holmes, The Path of the Law, supra note 26, at 465, ColLECTED PAPERS, 181.

12 Holmes, Law in Science-Science in Law, op. cit. supra note 26, at 461, Collected Papers, 240. 
embody the preference of a given body in a given time and place." 43

The denial that rules and principles of law pre-exist as readymade major premises for deductive syllogisms, by means of which the legal relations of parties in new cases can be determined without a consideration of the consequences, is sometimes thought to involve the assertion that there are no rules and principles of law. To this we may reply with John Dewey that "In denying that the meaning of any genuine case of deliberation can be exhausted by treating it as a mere case of an established classification, the value of classification is not denied. It is shown where its value lies, namely, in directing attention to resemblances and differences in the new case, in economizing effort in foresight. To call a generalization a tool is not to say it is useless; the contrary is patently the case. A tool is something to use. Hence it is also something to be improved by noting how it works. The need of such noting and improving is indispensable if, as is the case with moral [legal] principles, the tool has to be used in unwonted circumstances. Continuity of growth, not atomism, is thus the alternative to fixity of principles and aims." ${ }^{4}$

${ }_{43}$ Holmes, The Path of the Law, supra note 26 , at 465 , ColnECTED PAFEns, 181.

14 DEWEY, op. cit. supra note 30 , at 244-245. 